\title{
Evolution education in Scotland, and around the world
}

\author{
J.R. Downie \\ School of Life Sciences, Graham Kerr Building, University of Glasgow, Glasgow G12 8QQ \\ E-mail: roger.downie@glasgow.ac.uk
}

\section{INTRODUCTION}

Evolutionary geneticist Theodosius Dobzhansky (1973) wrote that "nothing in biology makes sense except in the light of evolution". Although there were important antecedents, what we now think of as the "theory of evolution" started public life at a meeting of the Linnean Society in London in 1858 , where papers by Charles Darwin and Alfred Russell Wallace were read proposing the process of natural selection as the means by which organisms could change over time. This was followed in 1859 by the publication of Darwin's book On the Origin of Species (Darwin, 1859). Thereafter, Darwin published several other books and revised editions of the Origin further articulating and expanding his ideas on the process that became known as "evolution". Let us not forget Wallace, who made later important contributions to our understanding of biogeography and is commemorated by Wallace's Line marking a discontinuity in animal distributions in the Far East. Since the early work, thousands of scientific papers and many books have been written more fully documenting, articulating and testing Darwin and Wallace's essential ideas; several scientific journals are devoted to the topic, like Evolution and the Journal of Evolutionary Biology.

The theory of evolution encompasses a number of basic propositions concerning the history of life on Earth:

- The Earth is very ancient (billions of years old) and so is the origin of life on Earth.

- Species of organisms are related by descent with modification.

- Organisms change over generations, mostly slowly; the changes are mostly adaptive, fixed in populations by the process of natural selection.

- Although most of the heritable variations on which natural selection works are generated randomly, the close relationship between environmental conditions and natural selection means that evolutionary change is anything but random.

- Evolution is an inescapable part of life, continually leading to alterations in the characteristics of living organisms: there is no final perfect state, and no state which organisms strive to attain.

- Human beings are related by descent to other animal species.
Different biologists might add to or slightly alter this set of propositions, but it will suffice for the purposes of this contribution. Among biological scientists, this set of propositions is uncontroversial and agreed. Despite this, the general public is not so sure, particularly in some countries. Mostly, the public do not feel competent to challenge scientific ideas and evidence, but a few cases are exceptional, the most obvious being evolution, anthropogenic climate change, and sometimes the causes of and how to cure disease. Evolution is generally challenged for religious reasons: it contradicts the particular creation story embedded in a particular religion's founding texts or traditions. The fact that each major religion tends to have its own, different creation story makes these challenges especially odd, and the leaders of many religions have come to terms with the idea that their creation stories are just that, stories which perhaps provide some guidance, but not factual accounts of what happened. The problem mainly arises where particular religions insist on the literal truth of their texts, i.e. the religions we label "fundamentalist".

\section{MY INTEREST IN EVOLUTION ACCEPTANCE AND REJECTION}

I became interested in evolution acceptance and rejection, and what they imply for educational strategies, when teaching evolution in the foundation Biology course at Glasgow University in the 1980s. I was aware of the high levels of evolution denial in the U.S.A., and wondered whether this was simply an American issue, as many thought at the time, or whether it was more widespread. We surveyed Glasgow biology students over nine sessions (and medical students over one), 1987-1999, and published the results in 2000 (Downie \& Barron, 2000). This was apparently the first such survey of U.K. students.

The basic question we asked was: "Do you accept that some kind of biological evolution, lasting many millions of years, has occurred on Earth?" Over the years, 3.9 to $11.3 \%$ of biology students (and $10.2 \%$ of medical students in one year) rejected evolution. You might regard this rejection level as low, but recall that these are biology or medical students, and remember Dobzhanky's statement on the centrality of evolution to biology.

Jumping to autumn 2016, an invitation came out of the blue from two U.S.A.-based science educators, Hasan 
Deniz and Lisa Borgerding, to contribute a chapter to a book to be titled Evolution Education around the Globe. The invitation resulted from the 2000 paper and a few others since then. I accepted on condition I could bring on board some helpers: Paul Braterman who is knowledgeable on the incursions of creationists into schools; Ronan Southcott, a biology teacher whose masters research on evolution acceptance I supervised; Naomi Barron, my wife, who helps with data analysis. The research and writing were intense because the editors were working to a tight deadline. After chapter submission, all principal authors took part in the review process, with each reviewing two other chapters and responding to the comments on their own chapter. All this plus some attempts at standardisation took time. The book was eventually published as an e-book by Springer International in July 2018 (Deniz \& Borgerding, 2018). The main aim of this article is to give a snapshot of the findings, including ours from Scotland.

\section{THE BOOK}

\section{Overall contents and strategy}

In addition to introductory and concluding chapters by the editors, Evolution Education around the Globe (Deniz \& Borgerding, 2018) has 22 chapters on different parts of the world (Table 1).

As the editors acknowledge, the coverage is patchy, with some important gaps: no Russia (evolution was enthusiastically embraced under communism, although in a distorted form, but what has happened since?), no China (except Hong Kong, rather a special case), only one African country (except for some coverage of north African Arab states). But the book is 464 pages long.

Authors were asked to address six themes:

- Public acceptance of evolutionary theory within the social and cultural context of their country or region.

- Whether there are anti-evolution movements in the country or region.

- The place of evolutionary theory in the curriculum.

- The emphasis given to evolutionary theory in the curriculum.

- Biology teachers' attitudes towards evolutionary theory.

- $\quad$ Suggestions to improve evolution education in the country or region.

The focus of most chapters is on evolution education at school level, but some also go into tertiary education coverage. To help make comparisons, each chapter contains some account of the structure of the education system in the country and how curricula are decided. All authors were given an approximate word limit, but chapters range in length from 13 pages (England's) to 28 pages. Ours at 26 pages is one of the longest.

\section{Overall conclusions}

Table 2 summarises the school level at which evolution is first taught.

\begin{tabular}{ll}
\hline Region & Chapters \\
\hline North America & Four on different states in the USA \\
Central and South America & Mexico, Brazil, the Galapagos Islands (Ecuador) \\
Europe & England, Scotland, Greece, France, German-speaking countries \\
Middle East & Turkey, Iran, Arab states \\
Asia & Hong Kong, Indonesia, Malaysia (two chapters), Philippines \\
Africa & South Africa \\
Oceania & New Zealand \\
\hline
\end{tabular}

Table 1. Coverage by region and countries in the book Evolution Education around the Globe (Deniz \& Borgerding, 2018).

\begin{tabular}{ll}
\hline School Level & Countries \\
\hline Primary, before age 10 & England, France, NZ, Philippines, U.S.A. (some states) \\
Middle, age 10-13 & Austria, Germany, Greece, Iran, Kuwait, Luxembourg, Mexico, Scotland, South \\
& Africa, Switzerland, U.S.A. (some states) \\
High school, above 14 & Brazil, Egypt, Greece, Hong Kong, Indonesia, Malaysia ${ }^{1}$, Syria, Tunisia, U.S.A. \\
& (some states) \\
Not required/omitted & Lebanon, Malaysia ${ }^{1}$, Turkey (after 2017) \\
Banned & Algeria, Morocco, Oman, Saudi Arabia \\
\hline
\end{tabular}

Table 2. School levels at which evolution first appears in the curriculum in different countries. ${ }^{1}$ Malaysia appears twice because there are two chapters, with strikingly different accounts of the situation. One states that evolution is taught in the senior school biology curriculum; the other that evolution has been deleted as part of an overall Islamification of the education system. 
Some countries appear more than once, partly because of internal variation, especially in the U.S.A. where individual states have a lot of autonomy. Actual banning of evolution is found only in a few predominantly Muslim countries, but it should not be deduced from this that there is agreement in Islamic countries that evolution is against their religion; note, for example, the early introduction of evolution into Kuwaiti and Iranian schools. I do not here attempt to cover the whole book, but rather pick out some themes.

Part of the book's context is an international survey of the general public by Miller et al. (2006) of the levels of acceptance of evolution in 34 countries, using the level of agreement with the statement: "Human beings, as we know them, developed from earlier species of animals" as the criterion. The findings were that in most European countries and Japan acceptance was $75 \%$ or higher, in the U.S.A. it was only $40 \%$, and in Turkey, it was a low $25 \%$.

\section{ISLAM AND EVOLUTION \\ Turkey}

Turkey was the only predominantly Muslim country in the sample collected by Miller et al. (2006). It is notable that the survey statement does not use the name "Darwin", or the word "evolution", but does focus on human origins, unlike the statement we used for Glasgow biology students, which used the term "biological evolution" and referred to its long time scale, but did not mention humans. It is very probable that differences in survey questions make a major impact on the responses.

Of the majority Muslim countries, the book covers Turkey (officially 100\% Muslim), Iran (98\% Muslim), Indonesia (87\% Muslim), Malaysia (61\% Muslim) and a set of Arab states (89-100\% Muslim). Attitudes to evolution and its teaching in these countries are deeply influenced by religion, politics and history.

For example, in Turkey, after the fall of the Ottoman Empire at the end of World War 1, the new leader, Kemal Ataturk initiated a transformation of society. The Ottoman Turkish literacy level was only $10 \%$. Ataturk brought in a secular education system, including the teaching of evolution in elementary and secondary schools, in the 1930s. This was not welcomed by religious conservatives, and Darwin and evolution were excluded soon after Ataturk's death in 1938. Turkey remains a political battleground between those who welcomed Ataturk's secularisation of the state and those who wish to re-embed Islam as a governing system (Mugaloglu, 2018).

In 2006, Harun Yahya, a Turkish Islamist with American creationist backing, published and widely distributed (free) volume 1 of Atlas of Creation which argued that the fossil record shows no evidence of evolutionary changes (Yahya, 2006), with volumes 2-4 published up to 2012. It is hard to know what influence the book has had. Evolution was re-instated into the curriculum after the 1940s but a series of Turkish curriculum reforms in 1999, 2005, 2013 and finally 2017 have ended with the removal of "evolution" and "Darwin" as terms for use in schools. According to the head of the curriculum board "students are too young to understand controversial subjects”.

\section{Arab states}

In the Arab states, school coverage of evolution goes from bad to worse. Evolution is included in the curriculum of four Arab states: Egypt, Syria, Tunisia and Kuwait, but causes conflict. In Egypt, teachers are reported to instruct students to study evolution, since it is required for examinations, but not to believe it, since it conflicts with religion. In Jordan, evolution is taught in very general terms, along with relevant Qur'an verses. Evolution is banned from schools in Saudi Arabia, Oman, Algeria and Morocco. In Saudi, evolution is mentioned in a grade 12 biology text as an erroneous and blasphemous theory which contradicts the teachings of Islam. Strangely, this situation changes in some Saudi universities where courses on evolution are available and academics pursue research on evolutionary themes, often in collaboration with researchers abroad. As the chapter writer notes, the research is published in English in international journals, far from the sight of the religious police (BouJaoude, 2018).

\section{Iran}

Iran is an Islamic Republic, with religion as the basis of the government. However, as in most things, Iran follows almost the opposite course to Saudi Arabia in the context of evolution. Like Turkey, Iran underwent huge societal change in the 1920s, with a western-style educational system introduced, modelled on that of France. Science and technology were seen as the future for the country, and several new science-based universities, such as that at Shiraz, were founded. The Islamic revolution of 1979 led to a temporary closure of the universities, and many curriculum changes. Perhaps surprisingly, this did not lead to a rejection of evolution, which had been introduced to the school biology curriculum prior to the revolution (Kazempour \& Amirshokoohi, 2018).

In Iran, the standard nation-wide curriculum introduces evolution in the final year of primary school, with coverage of Earth history, emergence and evolution of living organisms, the colonisation of land, dinosaurs and extinctions. Junior secondary includes a more detailed treatment with natural selection and mutations. The upper secondary biology text has a 40 page chapter on evolution, including the statement: "nearly all biologists to-day have accepted that Darwin's theory can explain the basis for the diversity of life on earth." The only stumbling block is human evolution. Iranian education accepts natural selection within the human population, but not the origin of humans from other animals. This means that Iran would be classed as rejecting evolution on the basis of the question used in the survey by Miller et al. (2006), but not in ours (Downie \& Barron, 2000). 


\section{CRUCIBLES OF EVOLUTION-1: GALAPAGOS, INDONESIA AND GREECE}

The theory of evolution has close associations with a number of places: I was interested to find how well this showed up in the associated book chapters.

\section{Galapagos}

The Galapagos chapter (Cotner \& Moore, 2018; Moore is an eminent evolution education researcher and was for many years editor of the journal American Biology Teacher) is exemplary. They note that the few hundreds of people resident on the islands when Darwin visited have swollen to 25,000 residents, with serious consequent impacts on the environment, and augmented by 170,000 annual visitors. Tourism contributes $70 \%$ of the islands' earnings, and most of this is Darwin-based. There are Darwin street names, statues, merchandise and the Darwin Research Station with its visitor facilities.

Cotner \& Moore (2018) put forward a hypothesis: that Galapagos residents would be better acquainted with evolutionary theory and more accepting of its conclusions than people elsewhere. A Pew Research Centre 2014 survey of religion in Latin America, including some Caribbean islands found levels of acceptance of human evolution ranging from a low of $41 \%$ in the Dominican Republic to a high of $74 \%$ in Uruguay, with Ecuador, of which the Galapagos are part, at only $50 \%$.

Cotner \& Moore (2018) surveyed 38 out of the 43 (88\%) biology and natural science school teachers working on the Galapagos, all of whom had college level education from mainland Ecuador. The rate of acceptance of evolution was high, $76 \%$ using the human evolution question, but knowledge of the details was often poor. All were aware of the Origin, but only 50\% knew approximately the time of Darwin's visit to the islands (many chose 1535, rather than 1835!). Around 90\% were proud of Darwin's connection with the islands and enjoyed teaching about evolution and the islands' role, but $80 \%$ felt uncomfortable teaching about evolution, and perceived a conflict with religion.

\section{Indonesia}

I had hoped to find some similar recognition in Indonesia, where Wallace, unwell on the island of Ternate, wrote the paper on natural selection that stimulated Darwin to break his decades of silence at the Linnean Society in 1858; and where he established the key discontinuity in animal distribution later known as Wallace's line. Sadly, the Indonesia chapter (Rachmatullah et al., 2018) has nothing on Wallace. However, it does recount the country's efforts to modernise its science education. Following a terrible ranking (61st out of 69) in an international assessment of science literacy, Indonesia introduced a new science curriculum in 2013. Evolution is included in the secondary school biology curriculum, but "alternatives" such as the views of Harun Yahya, and intelligent design are discussed. The chapter reports a study of pre-service biology teachers who displayed a poor understanding of evolution concepts. As is common throughout the book, evolution acceptance among these trainee teachers was strongest for micro-evolution (within species), intermediate for macro-evolution (the origin of new species) and weakest for human evolution. Indonesia is the most populous majority Muslim country in the world, and, like Iran, shows that religion is not necessarily in conflict with science.

\section{Greece}

The scientific study of animals began in Greece, with several books by Aristotle (384-322 B.C.), such as Enquiries into Animals (Leroi, 2014). Although Aristotle was not an advocate of evolutionary change, he was the first person we know of to make serious studies of living organisms, what they do and how they are constructed, and his findings were not significantly improved on for many centuries. The chapter on Greece (Kampourakis \& Stasinakis, 2018) notes that Darwin's "Origin" was not translated into Greek until 1915 (contrast with Germany where the first full translation appeared in 1860, within a year of first publication). However, there has been no serious religious objection to evolution in Greece. Deficiencies in evolution education there derive from poor preparation of teachers and a highly constrained educational structure. In correspondence, the authors regret the omission of Aristotle from the curriculum, and the absence of a consideration of the nature of science and its history in general.

\section{CRUCIBLES OF EVOLUTION-2: FRANCE, ENGLAND AND SCOTLAND \\ France}

French science played a key role in the emergence of evolutionary ideas (Quessada \& Clement, 2018). One of Darwin's antecedents was Lamarck whose promotion of evolutionary change was strenuously opposed by his Natural History Museum of Paris colleague Cuvier in the early 19th century (Stott, 2012). French state schools were secularised in the late 19th century, and evolution became part of the national school curriculum from that time. French science clung on to Lamarck's version of evolution well into the 20th century (the idea of change being based on individual striving, rather than on selection on population variability pools, and of evolution being directed towards particular ends rather than being directionless, which was especially promoted by the priest-paleontologist Teilhard de Chardin). Now, however, a more Darwinian view is fully accepted. In schools, Yahya's notorious Atlas of Creation (2016) was widely distributed in 2008, but the Ministry of National Education took rapid action: schools were forbidden from putting it in their libraries. (I remember being asked by the Principal of the University of Glasgow what he should do with the copy he had been sent. My view was that students' understanding of the evidence for evolution should be robust enough to see through Yahya's claims, so I had no objection to the book being shelved in the University of Glasgow Library; but schools are probably a different case). Overall, France comes fourth highest for evolution acceptance in survey by Miller et al. (2006). Evolution education begins in 
primary school and deepens through the secondary years.

\section{England}

Darwin spent most of his life in England, largely in Kent, with one year as a medical student in Edinburgh, then, more famously, his voyage on The Beagle, 183136. Wallace also spent most of his life, when not on collecting trips abroad, in England. The Linnean Society meeting announcing their idea of natural selection as a process for evolutionary change was in London. So England is central to the theory of evolution. It is also important to the development of biology education, with Thomas Henry Huxley promoting science education in universities through his work on several Royal Commissions. Oddly, Huxley's influential biology courses (e.g. Huxley and Martin, 1875) were heavily weighted to comparative anatomy, rather than to the study of living animals, or to the evidence for evolution, despite his public role as "Darwin's bulldog" (Ruse, 1997).

The book's England chapter is by Michael Reiss (2018), an interesting choice of author. Reiss is professor of Science Education at University College London's Institute of Education, as well as being an ordained Church of England priest. He was for a time director of education at the Royal Society of London, but resigned in 2008 following a controversy that developed from his speech to that year's British Association for the Advancement of Science meeting in Liverpool. His speech alluded to pupils who have creationist views, and he contended that science teachers risk alienating such pupils by simply dismissing creationism out of hand. He said that teachers "should take the time to explain how science works and why creationism has no scientific basis". Some felt that Reiss's resignation was more damaging to the Royal Society than to Reiss himself. Interestingly, Reiss does not mention this episode in his chapter, although he does write extensively on antievolution opinion in England. In my view, he rather exaggerates this, writing "evolution is now seen in England as a site of contestation within the curriculum", while at the same time quoting the Department of Children, Schools and Families 2007 guidance on the topic:

"Creationism and intelligent design are not part of the science National Curriculum... and should not be taught as science. However, there is a real difference between teaching ' $x$ ' and teaching about ' $x$ '. Any questions about creationism and intelligent design which arise in science lessons, for example as a result of media coverage, could provide the opportunity to explain and explore why they are not considered to be scientific theories and, in the right context, why evolution is considered to be a scientific theory."

Reiss notes that the science curriculum in English primary schools now includes evolution, but is hampered by the "small proportion of primary teachers who have learnt biology since they were 16 years old". This is a common worry from many chapters throughout the book.
Much of Reiss's chapter is about dealing with pupils who enter science classes with an anti-scientific, usually fundamentalist religious, worldview, and how hard it is to change such minds. I agree that it is hard, but an issue he does not tackle is why society feels it legitimate for young people to have their minds so brain-washed in the first place.

\section{Scotland}

I last discussed the public response in Scotland to the theory of evolution in a The Glasgow Naturalist editorial (Downie, 2001a) and briefly in an article on Glasgow Natural History Society's history (Downie, 2001b). The Society traces its origin back to 1851, just seven years before Darwin and Wallace's papers were read to the Linnean Society. Did the new ideas impact on the Society? The archives show that Professor John Scouler, honorary president of the Society, and who had visited the Galapagos a decade before Darwin (Nelson, 2014), addressed the Society twice, in 1862 and 1863 (publishing his views in a paper: Scouler, 1863) on the transmutation and permanence of species. He was critical of the idea of natural selection and did not think that Darwin had put forward anything substantially new. Later, John Young, Professor of Natural History at the University of Glasgow, was also somewhat sceptical in two talks to the Society in 1868 and 1892.

How then can I claim Scotland as a "crucible of evolution"? There are several reasons: first, Darwin's interests in natural history were greatly encouraged during his year as a reluctant medical student in Edinburgh, by getting to know Robert Grant, then researching the nature of sponges, who persuaded Darwin to join the local natural history society. He did so, and published his first paper through the society, aged 18. Second, Robert Chambers, radical Scottish writer, published (anonymously) The Vestiges of the Natural History of Creation (1844), asserting that the Earth is very ancient and that species are changeable, deriving his ideas from Darwin's grandfather Erasmus, among other influences. Although the book was condemned by the churches and by most academics, it was very widely read and helped create a climate susceptible to new ideas. Third, Scottish geological discoveries were influential. Hugh Miller was a devout Christian, but also an excellent geologist: it was clear to him that the Earth must be much older than the Bible suggests. Another Scot, James Croll, estimated the Earth's age as around 500 million years, much nearer to what Darwin's theory required than the estimate made by Lord Kelvin. Despite the cool reception in Glasgow, the basic idea of evolution was quickly accepted in Edinburgh, which hosted the 1871 British Association for the Advancement of Science meeting, including several talks on evolutionary themes.

I now turn to evolution education in Scotland. In early 20th century Scottish schools, science was mainly physics and chemistry. Prior to the publication of a new biology syllabus in 1968, fewer than 1000 pupils a year took national Scottish examinations in all the branches of biology. This has changed dramatically. By 2010, 
biology was the third most popular subject studied in Scottish schools. In 2011, Standard Grade Biology presented over 20,000 candidates. We are now in the era of the Curriculum for Excellence: how well does it deal with evolution?

In the general science curriculum, the theme Planet Earth introduces biodiversity and the inter-dependence of living organisms at level 4 (secondary year 3), a first hint of evolution. At year 4, the National 5 Biology syllabus has a chapter on evolution including natural selection. So far so good, although introduced later than in France and England, and not all pupils take National 5 Biology. After that, there is a problem: pupils choose between Higher courses (examined in year 5) in Biology or Human Biology, with those hoping to study medicine often preferring Human Biology. Higher Biology has several chapters on evolution, taking the subject to a deeper level. Human Biology has none, not even any coverage of human evolution, a very disappointing situation.

In the book, our chapter (Downie et al., 2018) reports on evolution education in schools and in tertiary education, and analyses the attitudes to evolution of Scottish biology teachers. As in other countries, school teachers are expected to teach evolution after remarkably little learning of the subject themselves (many had no more than a University first year level of evolution content in their pre-teacher training degrees). The majority of our sample of 149 Scottish biology teachers felt that evolution is adequately covered in the curricula, except for Higher Human Biology; 83\% agreed that the theory of evolution is a valid scientific explanation for the occurrence and diversity of organisms past and present. It is a worry that $15 \%$ did not agree.

Our chapter discusses the prevalence of anti-evolution influences in Scottish schools. In addition to learning about the origin of biodiversity in the science curriculum, pupils are exposed to Religious and Moral Education, a core primary and early secondary school theme. At senior school levels, this becomes an optional course in Religious, Moral and Philosophical studies. The course textbook for Higher level (Walker, 2016) is sound on the science of the origins of the Universe and life on Earth. However, at primary school level, the influence of the head teacher can be considerable, for example in the choice of visiting school chaplains. It is not uncommon for children to learn about the Roman invasion of Britain and Noah's Ark as if they had equal status as history. A representative of a U.S.A.-based fundamentalist church acted as chaplain to a school near Glasgow for some years, and the first parents knew of his activities was when children brought home a book stating that evolution is an unscientific lie used to promote immorality. It is a continuing anomaly of Scottish education that, by law, each Local Authority education committee includes three unelected church appointees, one Protestant, one Catholic, and one other.

We also report on our work on evolution acceptance and rejection by students at the University of Glasgow, taking further our earlier work (Downie \& Barron, 2000). We were pleased to find that there is a slow downwards trend in evolution rejection among Glasgow biology students, and that first year evolution rejectors have often changed their minds by final year. Unfortunately, it appears that the change results from realising that their religion is more accepting of evolution than they had thought, rather than a serious consideration of the evidence. Our data show that amongst the main religions our students adhere to, evolution rejection is significantly higher among Muslim than among Christian students. When we ask students why they reject evolution, the reason given overwhelmingly is that they prefer to accept a religious creation account. We find it alarming that young people, starting on a career in science, can think in this way: that a set of beliefs absorbed in their youth can over-rule scientific evidence.

\section{CONCLUSIONS}

Here is a statement from the InterAcademy Panel on International Issues, representing the academies of science of countries around the world and accepted by 67 countries, including Egypt and Morocco: "We, the undersigned Academies of Science, have learned that in various parts of the World, within science courses taught in certain public systems of education, scientific evidence, data and testable theories about the origins and evolution of life on Earth are being concealed, denied, or confused with theories not testable by science. We urge decision makers, teachers, and parents to educate all children about the methods and discoveries of science, and to foster an understanding of the science of nature" (InterAcademy Partnership, 2006).

The book's chapters on Malaysia demonstrate the problem. Lay et al. (2018) describe how perceived conflict with religious beliefs has limited the coverage of evolution in Malaysian schools, but that there is fair treatment of the subject in form 6 Biology. However, the account from Osman et al. (2018) is more up to date, and reports the deletion of evolution from the country's school curriculum. They describe the increasingly strong influence of "Islamic values": "The acceptance of an 'Islamic' approach to science is based upon the notion that the scientific methods are not the sole way to knowledge acquisition, but places equal importance on the other way of knowing such as intuition and revelation...More importantly, the insertion of Islamic and moral values in teaching science is to make students realise that science is not only a way of gaining new knowledge but also a means of appreciating and realising the presence and greatness of the Creator."

The idea that intuition and revelation are of equal value to scientific procedures in acquiring knowledge about the natural world will be profoundly damaging to the development of science of any kind in Malaysia and any other countries where this notion has taken hold.

There are many challenges in the teaching of any aspect of science, including evolution: at what curricular stage to start; to what depth to go, and how gradually; does 
everyone need to know the subject in depth, or only students proceeding to a particular specialism? However, it is profoundly dispiriting in the 21 st century, over 150 years beyond Darwin and Wallace's original proposals, to find whole countries denying the science of evolution, not on the basis of any evidence, but on the basis of inculcated religious beliefs.

\section{ACKNOWLEDGEMENTS}

This paper is an expanded version of the (past) Presidential Address given to Glasgow Natural History Society on 18th September 2018. I thank Hasan Deniz and Lisa Borgerding for the invitation to contribute an article on evolution education in Scotland, which led to the talk; also my colleagues Paul Braterman, Ronan Southcott and Naomi Barron who contributed to the article. Chris Finlay kindly gave permission for a new survey of Glasgow Biology-1 students in 2016.

\section{REFERENCES}

BouJaoude, S. (2018). Evolution education in the Arab states: context, history, stakeholders' positions and future prospects. In: Deniz \& Borgerding (2018), pp. 297-312.

https://doi.org/10.1007/978-3-319-90939-4_16

Chambers, R. [Anonymous in first edition; named in later editions] (1844). The Vestiges of the Natural History of Creation. John Churchill, London. https://doi.org/10.5962/bhl.title.166197

Cotner, S. \& Moore, R. (2018). Evolution Education in Galapagos: what do biology teachers know and think about evolution? In: Deniz \& Borgerding (2018), pp. 137-151. https://doi.org/10.1007/978-3-319-90939-4_8

Deniz, H. \& Borgerding, L.A. (Editors). (2018). Evolution Education Around the Globe. eBook. Springer International Publishing, Switzerland. https://doi.org/10.1007/978-3-319-90939-4

Dobzhansky, T. (1973). Nothing in biology makes sense except in the light of evolution. The American Biology Teacher 35, 125-129. https://doi.org/10.2307/4444260

Darwin, C. (1859). On the Origin of Species by Means of Natural Selection, or the Preservation of Favoured Races in the Struggle for Life. John Murray, London. https://doi.org/10.5962/bhl.title.68064

Downie, J.R. (2001a). Evolution and religion: an unnecessary conflict? The Glasgow Naturalist 23(6), $1-3$.

Downie, J.R. (2001b). 150 years of Glasgow Natural History Society. The Glasgow Naturalist 23(6), 5761.

Downie, J.R. \& Barron, N.J. (2000). Evolution and religion: attitudes of Scottish first year biology and medical students to the teaching of evolutionary biology. Journal of Biological Education 34, 139145. https://doi.org/10.1080/00219266.2000.9655704

Downie, J.R., Braterman, P.S., Southcott, R. \& Barron, N.J. (2018). Evolution education and evolution denial in Scotland. In: Deniz \& Borgerding (2018), pp. 169-194. https://doi.org/10.1007/978-3-319-90939-4_10

Huxley, T.H. \& Martin, H.N. (1875). A Course of Practical Instruction in Elementary Biology. MacMillan and Company, London. https://doi.org/10.5962/bhl.title.57803

InterAcademy Partnership (2006). InterAcademy Panel (IAP) Statement on the Teaching of Evolution. http://www.interacademies.org/13901/IAP-Stateme nt-on-the-Teaching-of-Evolution

Kazempour, M. \& Amirshokoohi, A. (2018). Evolution education in Iran: shattering myths about teaching evolution in an Islamic state. In: Deniz \& Borgerding (2018), pp. 281-296. https://doi.org/10.1007/978-3-319-90939-4_15

Lay, Y.F., Ong, E.T., Han, C.G.K. \& Chan, S.H. (2018). A glimpse of evolution education in the Malaysian context. In: Deniz \& Borgerding (2018), pp. 357374. https://doi.org/10.1007/978-3-319-90939-4_19

Leroi, A.M. (2014). The Lagoon: How Aristotle Invented Science. Bloomsbury, London.

Miller, J.D., Scott, E.C. \& Okomoto, S. (2006). Public acceptance of evolution. Science 313, 765-766. https://doi.org/10.1126/science.1126746

Mugaloglu, E.Z. (2018). An insight into evolution education in Turkey. In: Deniz \& Borgerding (2018), pp. 263-280. https://doi.org/10.1007/978-3-319-90939-4_14

Nelson, E. C. (2014). John Scouler (c. 1804-1871): Scottish Naturalist: A Life with Two Voyages. Glasgow Natural History Society, Glasgow.

Osman, K., Razali, R. \& Bahri, N.M. (2018). Biological evolution education in Malaysia: where we are now. In: Deniz \& Borgerding (2018), pp. 375-390. https://doi.org/10.1007/978-3-319-90939-4_20

Quessada, M.-P. \& Clement, P. (2018). Evolution education in France: evolution is widely taught and accepted. In: Deniz \& Borgerding (2018), pp. 213234. https://doi.org/10.1007/978-3-319-90939-4_12

Rachmatullah, A., Nehm, R.H., Roshayanti, F. \& Ha, M. (2018). Evolution education in Indonesia: preservice biology teachers' knowledge, reasoning models, and acceptance of evolution. In: Deniz \& Borgerding (2018), pp. 335-356. https://doi.org/10.1007/978-3-319-90939-4_18

Reiss, M. (2018). Evolution education in England. In: Deniz \& Borgerding (2018), pp. 155-168. https://doi.org/10.1007/978-3-319-90939-4_9

Ruse, M. (1997). Thomas Henry Huxley and the status of evolution as science. In: Barr, A.P. (Editor). Thomas Henry Huxley's Place in Science and Letters: Centenary Essays. Georgia, Athens.

Stasinakis, P.K. \& Kampourakis, K. (2018). Teaching evolution in Greece. In: Deniz and Borgerding (2018), pp. 197-212. https://doi.org/10.1007/978-3-319-90939-4_11

Stott, R. (2012). Darwin's Ghosts: In Search of the First Evolutionists. Bloomsbury Publishing, London.

Walker, J. (2016). Higher RMPS: Religious and Philosophical Questions. Hodder Gibson, Paisley.

Yahya, H. (2006). Atlas of Creation. Volume 1. Global Publishing, Turkey. 